\title{
Evaluation of C-reactive Protein/Albumin Ratio According to Stage in Patients with Idiopathic Parkinson Disease
} İdiyopatik Parkinson Hastalı̆̆ı Tanısı Olan Hastalarda Evrelere Göre C-reaktif Protein/ Albümin Oranlarının Değerlendirilmesi

\author{
(1) Tamer Yazar1 , (1) Hülya Olgun Yazar² \\ 1 Ordu State Hospital, Clinic of Neurology, Ordu, Turkey \\ 2Ordu University Training and Research Hospital, Clinic of Neurology, Ordu, Turkey
}

\begin{abstract}
Objective: Identification of serum C-reactive protein (CRP)/albumin ratio according to disease stage in idiopathic Parkinson's disease (IPD) with the aim of collecting data about the role of inflammation and oxidative stress in etiopathogenesis and about CRP/albumin ratio's possible effects on disease progression.

Materials and Methods: The study was completed with 151 patients being staged according to the Modified Hoehn and Yahr (H\&Y) criteria and 150 healthy volunteers in the same age interval with patients. In our retrospective study, the Unified Parkinson disease rating scale (UPDRS) and H\&Y scales were applied to the patients with IPD diagnosed according to the diagnostic criteria of the "United Kingdom Parkinson Disease Society Brain Bank". Patient and control groups had venous blood samples taken for biochemical study after 12-14 hours of fasting.

Results: The serum albumin levels were lower, while serum CRP levels and CRP/albumin ratios were higher in the IPD group ( $\mathrm{p}<0.05)$ than in the control group. Serum levels of CRP/albumin ratio significantly increased in parallel with the progression of disease stage $(\mathrm{p}<0.05)$.

Conclusion: Our study supports the hypothesis that serum CRP/albumin ratio may be associated with the etiopathogenetic process of IPD as a biomarker of inflammation and oxidative stress. In order to detect chronic and progressive diseases such as IPD in the initial stages and to take precautions, it is important to evaluate the changes in easily accessible, cost-effective parameters such as serum CRP/albumin ratio.
\end{abstract}

Keywords: İdiopathic Parkinson's disease, inflammation, CRP/albumin ratio, oxidative stress, disease stage

Öz

Amaç: İdiyopatik Parkinson hastalığı (İPH) tanısı olan hastalarda hastalık evresine göre serum C-reaktif protein (CRP)/albümin oranının tespiti ile etiyopatogenezde enflamasyonun ve oksidatif stresin rolüne ve bu oranın hastalık evresinin ilerlemesi üzerindeki olası etkilerine yönelik veriler toplanması amaçlanmıştır.

Gereç ve Yöntem: Çalışma, modifiye Hoehn ve Yahr $(\mathrm{H} \& \mathrm{Y})$ kriterlerine göre evrelere ayrılan 151 hasta ve hastalarla aynı yaş aralı̆̆ı̆nda 150 sağlıklı gönüllü ile gerçekleştirilmiştir. Retrospektif olarak yapılan çalışmamızda, "Birleşik Krallık Parkinson Hastalığı Derneği Beyin Bankası" tanı kriterlerine göre İPH tanısı konulan hastalara Birleşik Parkinson Hastalığı Değerlendirme Ölçeği ve H\&Y ölçekleri uygulanmıştır. Hasta ve kontrol gruplarında 12-14 saat açlıktan sonra biyokimyasal çalışmalar için venöz kan örnekleri alınmıştır.

Bulgular: İPH grubunda serum albümin seviyelerinin düşük olduğu, serum CRP seviyesi ve CRP/albümin oranlarının yüksek olduğu gözlenmiş̧ir ( $<<0,05$ ). CRP/albümin oranının serum seviyelerinin hastalık evrelerindeki ilerlemeye paralel olarak istatistiksel olarak anlamlı düzeyde arttığ $\breve{g}_{1}$ tespit edilmiştir (p<0,05).

Sonuç: Çalışmamız, enflamasyon ve oksidatif stresin bir biyobelirteci olarak CRP/albümin oranının İPH etiyopatogenetik sürecinin bir göstergesi olarak kullanılabileceği hipotezini destekler niteliktedir. İPH gibi kronik, ilerleyici hastalıkların başlangıç evrelerinde tespiti ve önlemler alınabilmesi için, serum CRP/ albümin oranı gibi kolay ulaşılabilir, az maliyetli parametrelerdeki değişikliklerin değerlendirilmesi önemlidir.

Anahtar Kelimeler: İdiyopatik Parkinson hastalı̆̆1, enflamasyon, CRP/albümin oranı, oksidatif stres, hastalık evresi

Address for Correspondence/Yazışma Adresi: Tamer Yazar MD, Ordu State Hospital, Clinic of Neurology, Ordu, Turkey

Phone: +90 4522343232 E-mail: tamer.yazar@yahoo.com.tr ORCID: orcid.org/0000-0003-3054-6613

Received/Geliş Tarihi: 14.11.2018 Accepted/Kabul Tarihi: 01.02.2019

${ }^{\circ}$ Copyright 2019 by Turkish Neurological Society

Turkish Journal of Neurology published by Galenos Publishing House. 


\section{Introduction}

Idiopathic Parkinson disease (IPD) is the second most common neurodegenerative disorder after Alzheimer's dementia, which affects approximately 1-2\% of the population aged over 60 years. The substrate is characterized by progressive and chronic dopaminergic neuron loss in the nigra pars compact (1). Unilateral upper extremity onset, slowdown in fine movements, stiffness, incompetence/tremor, rigidity, bradykinesia and postural instability are the main symptoms of the disease. Gait disturbances, postural changes, speech disorder, dysphagia, sialorrhea, micrographia, autonomic dysfunction, seborrhea, disturbance in eye movement, conjunctivitis, pain, sensory complaints, depression, sleep disturbances, dementia, psychosis, and rapid eye movement sleep behavior disorder may be present in IPD $(2,3,4)$. Although the prevalence of the disease varies, it has been reported as 80.6-187/100,000 in the world and 111/100,000 in Turkey. Although different results have been reported in studies in various countries, it is known that the incidence of parkinsonism in general varies from 4.5 to $21 / 100,000$ annually (5).

The etiopathogenesis of selective loss of dopamine neurons in IPD is still unclear. However, increased evidence suggests that oxidative stress and inflammation play an important role in the degeneration of dopaminergic neurons in IPD $(6,7)$. Cellular stress factors (e.g. toxins, free radicals, dysfunctions in the ubiquitin/proteasome system) can lead dopaminergic cells to undergo apoptotic death $(8,9)$. Serum C-reactive protein (CRP) and albumin concentrations have recently been used as markers of systemic inflammation and oxidative stress in different diseases $(7,10,11,12,13,14,15,16,17,18,19,20,21,22)$.

In patients with IPD, the diagnosis of inflammation and oxidative stress in the early stages and taking measures to improve the motor and cognitive problems can contribute to the correction of the clinical results of the disease and to slowing down the progression of the disease.

In the present study, we aimed to collect data to test the hypothesis that the presence of CRP/albumin as a marker of the progression of the disease in IPD and its relationship with parameters of disease stage might guide us in understanding the etiology of the disease.

\section{Materials and Methods}

\section{Sample Size of the Research}

In this retrospective study, 150 patients who were diagnosed as having IPD according to the United Kingdom Parkinson's Disease Society Brain Bank Diagnostic Criteria, who were followed up and treated for at least 1 year, and who were applied unified Parkinson's disease rating scale (UPDRS), mini-mental state examination (MMSE), geriatric depression scale (GDS) and Hoehn and Yahr (H\&Y) scale in the neurology outpatient clinics of Ordu University Training and Research Hospital and Ordu State Hospital Department of Neurology and 151 agematched healthy subjects were included in the study. The data of the patient group were obtained from the neurology outpatient follow-up files, which were arranged by the researchers. Patients with a lack of data in follow-up files were not included in the study.
Patients with stage 4 and 5 IPD according to H\&Y scale, with diseases that would significantly affect mobility (e.g. cerebrovascular event causing bed dependence, advanced muscle disease, hip dislocation, decompensated heart failure, acute or chronic renal failure with fluid overload) with MMSE score $<25$ points and with GDS $>10$ points were not included in the study.

The control group consisted of healthy individuals in the same age range as the patients with IPD, with normal neurologic examinations, with a MMSE score $>24$ points, and with a GDS score $<11$ points.

In the IPD and control groups, the presence of chronic disease (except for regulated hypertension), smoking and alcohol use, the presence infectious disease, weight loss, obesity, and the presence of diseases that might lead to increased CRP/albumin value (e.g. gout, preeclampsia and eclampsia, pneumonia, leukemia, hemolytic anemia, pernicious anemia, lymphomas, polycythemia, kidney failure, hypoparathyroidism, ischemic heart disease, chronic liver disease, cirrhosis) were accepted as exclusion criteria.

\section{Data Collection Tools}

Neurologic examination findings, demographic characteristics, chronic diseases, the medical treatments used, educational status, and history of smoking/alcohol use of the patients and controls were recorded. The patients and controls were evaluated using the MMSE and GDS scores. The UPDRS and H\&Y scale data of the patients were recorded from the patient follow-up files and IPD stages were determined. The duration of disease, cognitive and motor functions (UPDRS), and disease staging (H\&Y scale) were evaluated.

In patients and controls, venous blood samples were taken for biochemical and hemogram tests after 12-14 hours of fasting.

\section{Unified Parkinson's Disease Rating Scale}

UPDRS is the most frequently used measure for the evaluation of patients with IPD. It consists of 4 parts: feeling and thinking (total 16 points), daily life (total 52 points), motor complications (total 92 points), and treatment complications (total 23 points). The increase in total score in this scale, which is a scoring system using 0-4 points, shows that the symptoms are increasing $(23,24)$.

\section{Modified Hoehn and Yahr Scale}

This scale is used for the staging of Parkinson's disease (PD). It is made up of five phases. As the stage progresses, the disease is in the advanced stage. Stage 0 means that there is no evidence of disease, and stage 5 means that the patient is dependent on the bed, which is the most advanced stage of disease (24).

\section{Standardized Mini Mental State Examination}

The MMSE was first published by Folstein et al. (25). It is a short, useful and standardized method that can be used globally to determine the cognitive level. It is composed of eleven items under five main headings including orientation, recording memory, attention, calculation, recall, and language. The total score is 30 points. The Turkish validity and reliability study was performed by Güngen et al. (26).

\section{Geriatric Depression Scale}

The GDS was developed by Yesavage et al. (1982) (27) and its validity and reliability study was performed by Yesavage et 
al. (1982) (27). It consists of 30 questions based on self-reporting and those are easy to answer for the elderly. Each response in favor of depression is worth one point, the other responses are worth zero points. Zero-ten points mean 'no depression', 11-13 points 'possible depression', and $\geq 14$ points 'definite depression'. The validity and reliability study was performed by two groups in our country $(28,29)$.

\section{Collection of Analysis Samples and Serum Collection}

Blood samples were obtained for analysis from all patients who were admitted to our hospital. The blood samples of the patients were taken between 08:00 and 12:00 in the morning after about 12 hours of fasting. In order to obtain serum, gel tubes with separators and potassium-EDTA tubes for blood count were used. Gel tubes with separators, which were delivered to the laboratory under appropriate conditions, were left for 20 minutes and then centrifuged for 10 minutes at $5000 \mathrm{rpm}$ to separate the serum.

Albumin, CRP, urea, and creatinine measurements were made in our laboratories using a Cobas 8000 series c702 modular analyzer, which is a closed system making spectrophotometric measures.

The blood count (hemogram) was measured using an $\mathrm{XN}$ 1000 in our laboratory. This device is a closed system analyzer that makes measures using fluorescence flow cytometry in all modes.

\section{Ethical Aspect of the Research}

Approval for the study was obtained from the Ethics Committee of Ordu University Training and Research Hospital (Decision No: 2018/160). There was no need for consent because the files were scanned retrospectively.

\section{Statistical Analysis}

Statistical analysis was performed using the SPSS 25.0 package program. Continuous measurements are presented as mean and standard deviation. The Mann-Whitney $U$ test was used to compare two groups of numeric values without normal distribution, the independent samples t-test was used to compare the samples with normal distribution. The Kruskal-Wallis test was used to compare the numeric values of three groups without normal distribution, and the one-way analysis of variance was used to compare the numeric values of three groups with normal distribution. Spearman's Rho test was used for correlation analysis. In all tests, $\mathrm{p}<0.05$ was accepted as statistical significance.

\section{Results}

There were no differences between the control and IPD groups in terms of age, serum urea, creatinine, and hemoglobin concentrations $(p>0.05)$. There were significant differences between the groups in terms of albumin, CRP, and CRP/albumin ratios $(\mathrm{p}<0.05)$. Serum albumin was lower and CRP and CRP/ albumin ratios were higher in the IPD group than in the control group $(\mathrm{p}<0.05)$ (Table 1$)$.

The ages of the patients became older, duration of disease longer, UPDRS score higher, serum urea, creatinine, CRP and $\mathrm{CRP} /$ albumin ratios higher, and albumin lower as the disease progressed $(\mathrm{p}<0.05)$ (Table 2$)$.

There was a significant correlation between serum CRP, albumin, and CRP/albumin ratios of the patients and age, duration of disease, and MMSE scores of the patients with IPD. There was a positive correlation between age and CRP/albumin and a negative correlation between age and albumin. No correlation was found between age and CRP. There were positive correlations between UPDRS, duration of disease, H\&Y, and CRP and CRP/albumin ratios. There were negative correlations between UPDRS, duration of disease, $\mathrm{H} \& \mathrm{Y}$, and albumin concentrations. As a result, as the age, duration of disease, UPDRS, and stage of disease progressed, $\mathrm{CRP}$ and CRP/albumin ratios increased and serum albumin decreased; there was no correlation only between age and CRP (Table 3).

\section{Discussion}

Although the etiopathogenesis of selective loss of dopamine neurons in IPD remains unclear, increased evidence suggests that oxidative stress, mitochondrial dysfunction, inflammation, and apoptosis associated with those are the main mechanisms of neuron loss. Chronic progressive dopaminergic neuron loss, $\alpha$-synuclein protein aggregates, Lewy bodies, Lewy neurites, glial activation, and inflammation in the substantia nigra pars compacta play important roles in the neuropathogenesis $(1,6,7,8,9)$. Clinical and experimental evidence suggest that PD is associated with neuroinflammatory processes such as microglial activation, T-lymphocyte infiltration, and blood-brain barrier dysfunction (30).

Hemogram and biochemical tests including CRP and albumin concentrations are simple and inexpensive tests that

\begin{tabular}{|lcllll|}
\hline \multicolumn{7}{|c|}{ Table 1. The data of the control and idiopathic Parkinson disease groups } \\
\hline & $\mathbf{n}$ & Mean \pm SD & n & Mean \pm SD & p \\
Age & 150 & $73.92 \pm 4.81$ & 151 & $72.56 \pm 7.48$ & 0.168 \\
Urea $(\mathrm{mg} / \mathrm{dL})$ & 150 & $31.46 \pm 4.49$ & 151 & $32.35 \pm 5.06$ & 0.139 \\
Creatinine (mg/dL) & 150 & $0.79 \pm 0.09$ & 151 & $0.78 \pm 0.09$ & 0.545 \\
Albumin (g/dL) & 150 & $4.54 \pm 0.27$ & 151 & $4.05 \pm 0.31$ & $<0.001$ \\
CRP (mg/dL) & 150 & $0.16 \pm 0.10$ & 151 & $0.21 \pm 0.13$ & $<0.001$ \\
Hemoglobin (g/dL) & 150 & $13.75 \pm 0.75$ & 151 & $13.69 \pm 0.88$ & 0.543 \\
CRP/albumin & 150 & $0.05 \pm 0.04$ & 151 & $0.08 \pm 0.09$ & $<0.001$ \\
$\begin{array}{l}\text { Statistical significance level p<0.05 } \\
\text { SD: Standard deviation, CRP: C-reactive protein, IPD: Idiopathic Parkinson disease }\end{array}$ & \\
\hline
\end{tabular}


Table 2. Data of the patients with idiopathic Parkinson disease according to the disease stage

\begin{tabular}{|c|c|c|c|c|c|c|c|c|c|c|c|}
\hline & \multicolumn{2}{|c|}{ Stage 1} & \multicolumn{2}{|c|}{ Stage 1.5} & \multicolumn{2}{|c|}{ Stage 2} & \multicolumn{2}{|c|}{ Stage 2.5} & \multicolumn{2}{|c|}{ Stage 3} & \multirow[t]{2}{*}{$\mathrm{p}$} \\
\hline & $\mathrm{n}$ & Mean \pm SD & $\mathrm{n}$ & Mean \pm SD & $\mathrm{n}$ & Mean \pm SD & $\mathrm{n}$ & Mean \pm SD & $\mathrm{n}$ & Mean \pm SD & \\
\hline Age & 30 & $67.57 \pm 3.79$ & 31 & $70.52 \pm 3.29$ & 30 & $73.40 \pm 3.04$ & 30 & $75.37 \pm 3.4$ & 30 & $76.03 \pm 13.9$ & $<0.001$ \\
\hline UPDRS & 30 & $25.87 \pm 3.95$ & 31 & $35.87 \pm 3.71$ & 30 & $48.67 \pm 4.4$ & 30 & $58.50 \pm 6.3$ & 30 & $76.43 \pm 5.79$ & $<0.001$ \\
\hline Urea $(\mathrm{mg} / \mathrm{dL})$ & 30 & $28.77 \pm 3.43$ & 31 & $32.76 \pm 4.74$ & 30 & $33.97 \pm 4.3$ & 30 & $33.43 \pm 5.4$ & 30 & $32.80 \pm 5.66$ & 0.003 \\
\hline Albumin $(\mathrm{g} / \mathrm{dL})$ & 30 & $4.39 \pm 0.19$ & 31 & $4.15 \pm 0.19$ & 30 & $4.08 \pm 0.1$ & 30 & $3.91 \pm 0.29$ & 30 & $3.73 \pm 0.28$ & $<0.001$ \\
\hline $\mathrm{CRP}(\mathrm{mg} / \mathrm{dL})$ & 30 & $0.16 \pm 0.09$ & 31 & $0.20 \pm 0.08$ & 30 & $0.23 \pm 0.14$ & 30 & $0.19 \pm 0.13$ & 30 & $0.27 \pm 0.15$ & 0.018 \\
\hline Hemoglobin (g/dL) & 30 & $13.69 \pm 0.80$ & 31 & $13.64 \pm 0.75$ & 30 & $13.52 \pm 0.8$ & 30 & $13.84 \pm 1.1$ & 30 & $13.74 \pm 0.92$ & 0.697 \\
\hline $\mathrm{CRP} /$ albumin & 30 & $0.08 \pm 0.19$ & 31 & $0.06 \pm 0.03$ & 30 & $0.09 \pm 0.04$ & 30 & $0.07 \pm 0.04$ & 30 & $0.10 \pm 0.06$ & 0.001 \\
\hline
\end{tabular}

Table 3. Correlations between the data of the patients with idiopathic Parkinson disease and C-reactive protein, albumin and C-reactive protein/albumin ratio

\begin{tabular}{|c|c|c|c|c|c|c|}
\hline & \multicolumn{2}{|l|}{ CRP } & \multicolumn{2}{|c|}{ Albumin } & \multicolumn{2}{|c|}{ CRP/albumin } \\
\hline & $\mathbf{r}$ & $\mathrm{p}$ & $\mathbf{r}$ & $\mathrm{p}$ & $\mathbf{r}$ & $\mathrm{p}$ \\
\hline Age & 0.146 & 0.074 & -0.601 & $<0.0001$ & 0.297 & $<0.001$ \\
\hline UPDRS & 0.172 & 0.034 & -0.730 & $<0.001$ & 0.312 & $<0.001$ \\
\hline $\begin{array}{l}\text { Disease } \\
\text { duration }\end{array}$ & 0.200 & 0.014 & -0.748 & $<0.001$ & 0.338 & $<0.001$ \\
\hline $\mathrm{H} \& \mathrm{Y}$ & 0.183 & 0.025 & -0.779 & $<0.001$ & 0.300 & $<0.001$ \\
\hline $\begin{array}{l}\text { Statistical si } \\
\text { UPDRS: Un } \\
\text { Yahr scale }\end{array}$ & ificance 1 & $\mathrm{el} p<0.0$ & & & & \\
\hline
\end{tabular}

provide important data about the quantitative and qualitative features of various blood cells. The CRP/albumin ratio has emerged as a prognostic and potential inflammatory marker in chronic neurologic diseases. CRP and albumin are parameters that can be reached more easily than other inflammatory cytokines including interleukin (IL)-6, IL-1 $\beta$ and tumor necrosis factor- $\alpha$ (10).

CRP is an acute phase protein synthesized in hepatocytes in response to pro-inflammatory cytokines during inflammatory/ infectious processes. Although it is known as a biomarker of acute inflammation, many large-scale prospective studies suggest that $\mathrm{CRP}$ is also associated with chronic inflammation (11). CRP is a biomarker of chronic inflammation and a direct participant of the pathologic process (31). Molecular genetic techniques have shown that CRP can be produced locally in the brain and CRP production increases in areas damaged by neurodegenerative processes such as Alzheimer's disease (AD) $(32,33)$. Ak1l et al. (10) showed that CRP concentrations were significantly higher in patients with PD than in healthy controls in their study performed with 51 patients with PD and 50 healthy controls. It has been shown that CRP concentrations rise in chronic diseases such as hemorrhagic cerebrovascular disease, AD, and PD $(11,12,13,14,15,16)$. In our study, in line with the literature, we found that serum CRP concentrations significantly increased as the disease stage increased in patients with IPD.

Hypoalbuminemia is an acute phase response associated with inflammation and oxidative stress. Homocysteine, uric acid (UA), albumin, and bilirubin are defined as laboratory parameters associated with oxidative stress. Low UA, albumin, and bilirubin concentrations were associated with many neurodegenerative diseases, including PD, but these changes in their concentrations as oxidative stress markers were not clarified as to whether they caused neurodegenerative diseases or they were results of the underlying process in the literature $(7,17,18,19,20,21,22)$. Several studies showed that there was a correlation between hypoalbuminemia and increased CRP concentrations and other acute phase proteins (34). It was reported that hypoalbuminemia was correlated with poor prognosis in patients with ischemic stroke (35). In one study, it was observed that there was an improvement in neurologic deficit when albumin was administered following acute intracortical hematoma (36). In various studies, serum albumin concentrations were found to be significantly reduced as the disease progressed (22). Similarly, the data of our study showed that serum albumin concentrations in patients with IPD decreased significantly in parallel with the increase in the disease stage.

To our knowledge, our study is the first to evaluate the serum CRP/albumin ratio according to disease stage in patients with IPD. In our study, the serum CRP/albumin ratio was found high in the IPD group. It was found that serum concentrations of $\mathrm{CRP} /$ albumin increased statistically significantly in parallel with progression in the disease stages. As the age, duration of disease, UPDRS, and stage of disease progressed, CRP and the CRP/ albumin ratio increased and serum albumin decreased, which were important findings of our study. There was no correlation only between age and CRP. The serum CRP/albumin ratio has been investigated in various diseases and different ratios were reported in the literature $(1,10,11,12,13,14,15,18,20,32,33,35,3$ $6)$. Therefore, the fact that we performed the study with a control group in the same age range as the patients was another important feature of our study. In general, all the data of our study were consistent with the literature. 


\section{Study Limitations}

Our study had some limitations. We did not evaluate the anthropometric (height, weight, waist, hip, calf and forearm circumference), demographic and nutritional characteristics, and educational status of the patients and controls, whether they performed regular exercise or the possible effects of drugs used in the patients and controls. The cross-sectional nature of our study prevented us from determining any causal relationship between the variables. In addition, the relatively small sample size was another limitation of our study. Despite being in the normal range of the laboratory, the differences in serum urea and creatinine concentrations between disease stages were accepted as a limitation of our study. Therefore, more prospective, comprehensive and large-scaled studies to evaluate the relation between IPD and serum CRP/albumin ratio are needed.

\section{Conclusion}

Our study supports the hypothesis that serum CRP/albumin ratio may be associated with the etiopathogenic process of IPD as a biomarker of inflammation and oxidative stress. In order to detect chronic and progressive diseases such as IPD in the initial stages and to take precautions, it is important to evaluate the changes in easily accessible, cost-effective parameters such as the serum CRP/ albumin ratio. More studies are needed to replicate our findings using longitudinal data.

\section{Ethics}

Ethics Committee Approval: This study was approved by the Ethics Committee of Ordu University Training and Research Hospital (Decision no: 2018/160).

Informed Consent: There was no need for consent because the files were scanned retrospectively.

Peer-review: Externally and internally peer-reviewed.

\section{Authorship Contributions}

Surgical and Medical Practices: T.Y., H.O.Y., Concept: T.Y., Design: T.Y., Data Collection or Processing: H.O.Y., T.Y., Analysis or Interpretation: T.Y., H.O.Y., Literature Search: T.Y., Writing: T.Y., H.O.Y.

Conflict of Interest: No conflict of interest was declared by the authors.

Financial Disclosure: The authors declared that this study received no financial support.

\section{References}

1. Kalia LV, Lang AE. Parkinson's disease. Lancet 2015;386:896-912.

2. Lökk J. Caregiver strain in Parkinson's disease and the impact of disease duration. Eur J Phys Rehabil Med 2008;44:39-45.

3. Yazar T, Karagöz Sakallı N, Baslo B, Kırbaş D, Yayla V. Motor unit number estimation in Idiopathic parkinson's disease. Düşünen Adam The Journal of Psychiatry and Neurological Sciences 2011;24:101-105.

4. Olgun Yazar H, Yazar T, Yancar Demir E, Çankaya S, Enginyurt Ö. Assessment of Mental Health of Carers According to Patient Stage of Idiopathic Parkinson's Disease. Ideggyogy Sz 2018;71:205-212.

5. Torun Ş, Uysal M, Gücüyener D, Özdemir G. Parkinson's disease in Eskişehir, Turkey. Eur J Neurol 1995;2:44-45.

6. Blesa J, Trigo-Damas I, Quiroga-Varela A, Jackson-Lewis VR. Oxidative stress and Parkinson's disease. Front Neuroanat 2015;9:91.
7. Gökçe Çokal B, Yurtdas M, Keskin Güler S, et al. Serum glutathione peroxidase, xanthine oxidase, and superoxide dismutase activities and malondialdehyde levels in patients with Parkinson's disease. Neurol Sci 2017;38:425-431.

8. Pankratz N, Foroud T. Genetics of Parkinson Disease. NeuroRx 2004;1:235242.

9. Gallagher DA, Schapira AH. Etiopathogenesis and treatment of Parkinson's disease. Curr Top Med Chem 2009;9:860-868.

10. Akıl E, Bulut A, Kaplan İ, Özdemir HH, Arslan D, Aluçlu MU. The increase of carcinoembryonic antigen (CEA), high-sensitivity C-reactive protein, and neutrophil/ lymphocyte ratio in Parkinson's disease. Neurol Sci 2015;36:423-428.

11. Luan YY, Yao YM. The Clinical Significance and Potential Role of C-Reactive Protein in Chronic Inflammatory and Neurodegenerative Diseases. Front Immunol 2018;9:1302.

12. Nadrowski P, Chudek J, Skrzypek M, et al. Associations between cardiovascular disease risk factors and IL-6 and hsCRP levels in the elderly. Exp Gerontol 2016;85:112-117.

13. Agca R, Heslinga M, Kneepkens EL, Van Dongen C, Nurmohamed MT. The effects of 5-year etanercept therapy on cardiovascular risk factors in patients with psoriatic arthritis. J Rheumatol 2017;44:1362-1368.

14. Taheri S, Baradaran A, Aliakbarian M, Mortazavi M. Level of inflammatory factors in chronic hemodialysis patients with and without cardiovascular disease. J Res Med Sci 2017;22:47.

15. Weinstein G, Lutski M, Goldbourt U, Tanne D. C-reactive protein is related to future cognitive impairment and decline in elderly individuals with cardiovascular disease. Arch Gerontol Geriatr 2017;69:31-37.

16. Towfighi A, Cheng EM, Ayala-Rivera M, et al. Randomized controlled trial of a coordinated care intervention to improve risk factor control after stroke or transient ischemic attack in the safety net: secondary stroke prevention by uniting community and chronic care model teams early to end disparities (SUCCEED). BMC Neurol 2017;17:24.

17. Schirinzi T, Di Lazzaro G, Colona VL, et al. Assesment of serum uric acid as risk factor for tauopathies. J Neural Transm (Vienna) 2017;124:11051108.

18. Çubukçu HC, Yurtdaş M, Durak ZE, et al. Oxidative and nitrosative stress in serum of patients with Parkinson's disease. Neurol Sci 2016;37:17931798.

19. Zhong LL, Song YQ, Tian XY, Cao H, Ju KJ. Level of uric acid and uric acid/creatinine ratios in correlation with stage of Parkinson disease. Medicine (Baltimore) 2018;97:10967.

20. Wei Z, Li X, Li X, Liu Q, Cheng Y. Oxidative Stress in Parkinson's Disease: A Systematic Review and Meta-Analysis. Front Mol Neurosci 2018;11:236.

21. Qin XL, Zhang QS, Sun L, Hao MW, Hu ZT. Lower Serum Bilirubin and Uric Acid Concentrations in Patients with Parkinson's Disease in China. Cell Biochem Biophys 2015;72:49-56.

22. Huang X, Ng SY, Chia NS, et al. Serum uric acid level and its association with motor subtypes and non-motor symptoms in early Parkinson's disease: PALS study. Parkinsonism Relat Disord 2018;55:50-54.

23. Jankovic J. Parkinson's disease: clinical features and diagnosis. J Neurol Neurosurg Psychiatry. 2008;79:368-376.

24. Ramaker C, Marinus J, Stiggelbout AM, Van Hilten BJ. Systematic evaluation of rating scales for impairment and disability in Parkinson's disease. Mov Disord 2002;17:867-876.

25. Folstein MF, Folstein SE, McHugh PR. "Mini-mental state". A practical method for grading the cognitive state of patients for the clinician. J Psychiatr Res 1975;12:189-198.

26. Güngen C, Ertan T, Eker E, Yaşar Y, Engin F. Standardize Mini Mental Test?in Türk Toplumunda Hafif Demans Tanısında Geçerlik ve Güvenilirliği. Türk Psikiyatri Dergisi 2002;13:273-281.

27. Yesavage JA, Brink TL, Rose TL, et al. Development and validation of a geriatric depression screening scale: a preliminary report. J Psychiatr Res 1982-1983;17:37-49.

28. Ertan T, Eker E. Reliability, Validity and Factor Structure of the Geriatric Depression Scale in Turkish Elderly: Are there different factor structures for different cultures? Int Psychogeriatr 2000;12:163-172.

29. Sağduyu A. Yaşlılar İçin Depresyon Ölçeği: Hamilton Depresyon Ölçeği ile Karşılaştırmalı Güvenirlik ve Geçerlik Çalışması. Türk Psikiyatri Dergisi $1997 ; 8: 3-8$ 
30. Tiwari PC, Pal R. The potential role of neuroinflammation and transcription factors in Parkinson disease. Dialogues Clin Neurosci 2017;19:71-80.

31. Vachatova S, Andrys C, Krejsek J, et al. Metabolic syndrome and selective inflammatory markers in psoriatic patients. J Immunol Res 2016;2016:5380792.

32. Yasojima K, Schwab C, McGeer EG, McGeer PL. Human neurons generate C-reactive protein and amyloid P: upregulation in Alzheimer's disease. Brain Res 2000;22;887:80-89.

33. Mancinella A, Mancinella M, Carpinteri G, et al. Is there a relationship between high C-reactive protein (CRP) levels and dementia? Arch Gerontol Geriatr 2009;49(Suppl 1):185-194.
34. Yeun JY, Levine RA, Mantadilok V, Kaysen GA. C-Reactive protein predicts all-cause and cardiovascular mortality in hemodialysis patients. Am J Kidney Dis 2000;35:469-476.

35. Cho YM, Choi IS, Bian RX, Kim JH, Ham JY, Lee SG. Serum albumin at admission for prediction of functional outcome in ischemic stroke patients. Neurol Sci 2008;29:445-449.

36. Belayev L, Saul I, Busto R, et al. Albumin treatment reduces neurological deficit and protects blood-brain barrier integrity after acute intracortical hematoma in the rat. Stroke 2005;36:326-331. 